8-1994

\title{
Seed Dispersal In A Marine Macrophyte - Implications For Colonization And Restoration
}

\author{
R J. Orth \\ Mark Luckenbach \\ College of William and Mary \\ Ken Moore
}

Follow this and additional works at: https://scholarworks.wm.edu/vimsarticles

Part of the Marine Biology Commons

\section{Recommended Citation}

Orth, R J.; Luckenbach, Mark; and Moore, Ken, "Seed Dispersal In A Marine Macrophyte - Implications For Colonization And Restoration" (1994). VIMS Articles. 1738.

https://scholarworks.wm.edu/vimsarticles/1738

This Article is brought to you for free and open access by the Virginia Institute of Marine Science at W\&M ScholarWorks. It has been accepted for inclusion in VIMS Articles by an authorized administrator of W\&M ScholarWorks. For more information, please contact scholarworks@wm.edu. 


\title{
SEED DISPERSAL IN A MARINE MACROPHYTE: IMPLICATIONS FOR COLONIZATION AND RESTORATION ${ }^{1}$
}

\author{
Robert J. Orth, Mark Luckenbach, and Kenneth A. Moore \\ School of Marine Science, Virginia Institute of Marine Science, College of William and Mary, \\ Gloucester Point, Virginia 23062 USA
}

\begin{abstract}
Seagrasses rely on both vegetative (rhizome elongation) and sexual (seeds) propagation for maintenance of existing beds and colonization of new areas. Yet mechanisms of seed dispersal and survival of seeds in new areas remain poorly described. We conducted seed dispersal experiments in the field and laboratory to better describe seed dispersal characteristics in one species, Zostera marina L. (eelgrass); the dominant seagrass species in the temperate zone of the United States, Japan, and Europe.

Seeds were broadcast by hand into unvegetated $5 \mathrm{~m}$ diameter plots at three locations over 3 yr (1989-1991) in the York River, Virginia (Chesapeake Bay). These sites had been previously vegetated but were devoid of any vegetation prior to (since 1972) and during the course of the experiments. Resultant seedling distributions closely matched broadcast patterns, with $80 \%$ of all seedlings found within the $5 \mathrm{~m}$ diameter plots, despite the fact that geophysical processes would appear sufficient to transport seeds greater distances. Wind records for the 2-mo period between seed broadcasting and germination revealed time-averaged wind speeds in excess of $40 \mathrm{~km} / \mathrm{h}$ on $\geq 12 \mathrm{~d}$ in each of the $3 \mathrm{yr}$ and galeforce winds $(72 \mathrm{~km} / \mathrm{h})$ in 2 of $3 \mathrm{yr}$. A three-dimensional hydrographic computer simulation model of the York River provided instantaneous current velocity estimates from which maximum bottom shear velocities $\left(u_{*}\right)$ in the study area were approximated (flood tide: $1.26 \mathrm{~cm} / \mathrm{s}$, ebb tide: $1.20 \mathrm{~cm} / \mathrm{s}$ ). These estimates exceeded the critical erosion threshold $\left(u_{*_{\text {crit }}}=0.7 \mathrm{~cm} / \mathrm{s}\right)$ for $Z$. marina seeds determined from laboratory flume experiments. We postulate that small-scale topographic features on the bottom (burrows, pits, mounds, ripples) shield the seeds from the flow.

Our results suggest that seeds settle rapidly, dispersing only up to a few metres under the influence of currents and become rapidly incorporated into the sediment. The limited dispersal capabilities of seeds underscore the need to address restoration goals and questions of seagrass ecology in the context of landscape-scale distributional patterns and metapopulation analyses.
\end{abstract}

Key words: Chesapeake Bay, USA; colonization; current velocity; dispersal; macrophyte; seagrass; seeds; settling velocity; wind; Zostera marina.

\section{INTRODUCTION}

Seed dispersal in plants is generally presumed to provide for longer distance dispersal and colonization capabilities than vegetative propagation. A variety of mechanisms have evolved to take advantage of wind, water, and animal movements to facilitate seed dispersal (Ridley 1930, van der Pijl 1972, Howe and Smallwood 1982). Selective advantages to seed dispersal were posited by Howe and Smallwood (1982) to fall into three nonmutually exclusive alternatives: the escape hypothesis, which assumes greater seed and seedling mortality in the vicinity of adults; the colonization hypothesis, which emphasizes dispersal to disturbed, relatively noncompetitive habitats; and the di-

${ }^{1}$ Manuscript received 20 September 1993; revised 7 February 1994; accepted 18 February 1994. rected dispersal hypothesis, which envisions a mosaic habitat with distributed suitable microhabitats. Dispersal mechanisms are expected to evolve in the context of life history pattern responses to environmental conditions and selective pressures identified by one or more of these alternative hypotheses.

Seagrass species in shallow water coastal environments may rely to varying degrees upon vegetative or sexual reproduction for the maintenace of existing beds. Colonization of new, unvegetated areas, or recolonization of disturbed areas that may be spatially separated from existing beds, will depend on species-specific dispersal capabilities. Yet, mechanisms and patterns of dispersal have not been well described for most seagrass species. Analyses of seed dispersal characteristics, germination patterns, and seedling success are requisite for an understanding of dispersal strategies and colonization potentials for seagrasses. 
Seagrasses are declining worldwide, largely as a result of increased eutrophication in coastal waters (Thayer et al. 1975, Orth and Moore 1983a, Cambridge and McComb 1984, Giesen et al. 1990). Restoration efforts in several areas have emphasized reversing this trend and have focused on using seagrass recolonization and establishment as an indicator of habitat quality (Dennison et al. 1993). This presumes a knowledge of seed dispersal characteristics that generally is lacking. Effective management and restoration strategies will require information on the relative contributions of vegetative vs. sexual propogation in maintaining existing beds, as well as in dispersal to and colonization of new habitats. Specifically, the relationships among established beds, seed dispersal capabilities, germination requirements, and seedling survival will determine recruitment patterns that necessarily underly recovery potentials.

Eelgrass, Zostera marina L., a perennial seagrass species found along both coasts of North America, Europe, and Japan (den Hartog 1970), exhibits both vegetative and sexual reproduction. In the temperate waters of Chesapeake Bay, along the Atlantic coast of the United States, seeds are produced from late May to early June (Silberhorn et al. 1983). Mature seeds released from reproductive shoots are free to fall to the bottom or be transported by water currents at this time. Reproductive shoots with mature seeds may also be exported from the bed. Germination of seeds does not begin until mid-October in this region with the actual timing linked to incorporation of seeds into the sediment (Orth and Moore 1983b, Moore et al. 1993). Moore et al. (1993) have demonstrated greater germination rates for buried vs. unburied $Z$. marina seeds, with an apparent interactive effect of reduced oxygen and temperature acting to accelerate seed germination. Unlike many terrestial annual species for which a seed bank exists (e.g., Brown and Venable 1986), Z. marina seeds are not viable beyond their first season (Orth and Moore $1983 b$; numerous cores taken in the spring for fauna in this region have recorded only germinated and nonviable seeds [R. J. Orth, unpublished data].

Mechanisms affecting the dispersal of $Z$. marina seeds are not well understood. Current-mediated transport at the time of release may disperse seeds and bedload (hydrodynamically mediated rolling or saltation along the bottom) transport may redistribute them once on the bottom. The role of rare storm events in transporting seeds has not been investigated. Export of rafting reproductive shoots with seeds from the bed has been suggested as an important long distance dispersal mechanism (McRoy 1968). The relative contribution of this vs. direct seed release remains to be investigated. Although waterfowl have been suggested as a vehicle for seed dispersal (Arasaki 1950, McRoy 1968), the timing of seed production and germination in Chesapeake Bay precludes their role in seed dispersal in this area. The impacts of benthic fauna remain unknown.
The time period of 4-5 mo between seed release and germination is ample for several mechanisms to be involved.

We report here on field and laboratory experiments addressing seed dispersal characteristics of $Z$. marina. Seedling distributions from $3 \mathrm{yr}$ of seed dispersal experiments are coupled with wind data and current velocity simulations to elucidate the roles of geophysical processes in determining dispersal patterns. Laboratory flume investigations are used to determine hydrodynamic and transport characteristics of seeds. Our findings indicate limited dispersal capabilities of $Z$. marina seeds, suggesting (1) that none of the adaptive scenarios presented by Howe and Smallwood (1982) are operational in this system, (2) that recruitment limitation occurs in the establishment of new $Z$. marina beds, and (3) that an important historical component exists in the determination of regional landscape patterns of $Z$. marina distribution.

\section{Methods}

\section{Seed collection and storage}

Reproductive shoots with mature seeds were harvested by hand from an established $Z$. marina bed at the mouth of the York River, Chesapeake Bay, Virginia $\left(37^{\circ} 16^{\prime} \mathrm{N}, 76^{\circ} 20^{\prime} \mathrm{W}\right.$; Fig. 1), in late May to early June of 1989,1990 , and 1991, immediately prior to seed release (Silberhorn et al. 1983). Shoots were placed in nylon mesh bags, returned to Gloucester Point, $9 \mathrm{~km}$ upriver from the collection site, where they were placed in circular, $3.8-\mathrm{m}^{3}$, outdoor tanks. The tanks were aerated and supplied with continuously running seawater from an area in the adjacent York River that supports $Z$. marina beds. Following seed release, stems and leaf material were removed by sieving. Seeds were then kept under ambient conditions in the tanks until the initiation of the experiments.

\section{Seed disperal experiments}

Seed dispersal experiments were conducted in the York River in 1989, 1990, and 1991 at sites that once supported dense stands of $Z$. marina prior to 1972 but were now devoid of any seagrass (Orth and Moore 1984, Orth et al. 1992) (Fig. 1). Two sites were located on the north shore of the York River, Gloucester Point and Mumfort Island, $3 \mathrm{~km}$ upriver from Gloucester Point, and one site was located on the south shore, Yorktown, directly across from the Gloucester Point site. All three sites have been used for transplant experiments over the last decade, primarily with whole plants (R. J. Orth and K. A. Moore, unpublished data); however, long-term success of the transplants has been marginal. Preliminary work with seeds planted at these sites showed that seeds successfully germinate and grow in these areas through the spring and early summer, after which time high water column turbidity levels, in some years, result in complete mortality. 
In each of the $3 \mathrm{yr}, 5.0 \mathrm{~m}$ diameter circular plots were established in an unvegetated sandy area with a water depth of $\approx 0.5-1.0 \mathrm{~m}$ at mean low water (MLW). There was no naturally occurring vegetation in the vicinity of the plots. Seedlings observed later in the plot were assumed to be from the planted seeds.

Placement of the seeds in each plot was accomplished by gently broadcasting by hand a mixture of seeds and detrital material from the seed-holding tank onto the designated plot in September of each year, roughly 1-2 mo before seeds begin germinating naturally (Orth and Moore 1983b, Moore et al. 1993). A single individual walked along the perimeter of the circle casting a preset volume of seeds from $\approx 1 \mathrm{~m}$ above the water surface throughout the plot. The number of viable seeds broadcast was based on actual counts of seeds in replicate 5-mL portions of the seed lot for each year. Direct observations of this method revealed that seeds rapidly descended to the bottom.

In 1989, a single plot was established at each of the three locations. Approximately 30000 viable seeds were broadcast onto each plot on 8 September at low tide.

In 1990, three replicate plots were established at the Gloucester Point and Mumfort Island locations. Approximately 20000 viable seeds were broadcast onto each plot on 13 September during mid-ebb tide.

In 1991, six replicate plots were established at the Gloucester Point site. Approximately 40000 viable seeds were broadcast onto each plot on 30 September during early flood tide. Concurrently, two $5-\mathrm{mL}$ aliquots of seeds planted in sand in containers were then held in running ambient seawater in order to determine the proportion of seeds that sprouted successfully.

Seedling abundance both within and outside the plot was determined in April or early May of the following year by counting the number of seedlings in successive $0.25-\mathrm{m}^{2}$ quadrats placed along eight nonrandom transects emanating from the center of the circle, similar to the spokes of a wheel. In addition, the areas around the plots were surveyed for possible evidence of more widespread dispersal.

Seedling distributions were estimated from the quadrat data using a contour plot (Golden Software, Golden, Colorado, USA), which is developed using a kriging algorithm. Values for uncensused quadrats were interpolated as linear functions of the five nearest neighbors and outputs specified as density contours and threedimensional surface plots. Because this algorithm results in a very ragged boundary at the outer edge of the distribution where seedling density varies between 0 and 1 per quadrat, density plots are presented for regions greater than the 1 plant $/ 0.25 \mathrm{~m}^{2}$ contour. Estimates of the total numbers of seedlings were derived by summation of the density estimates for all quadrats within this contour, thus providing a conservative estimate. Averaged seedling density contour plots were produced by using mean values from the $0.25 \mathrm{~m}^{2}$ quadrats from each replicate plot within a site.

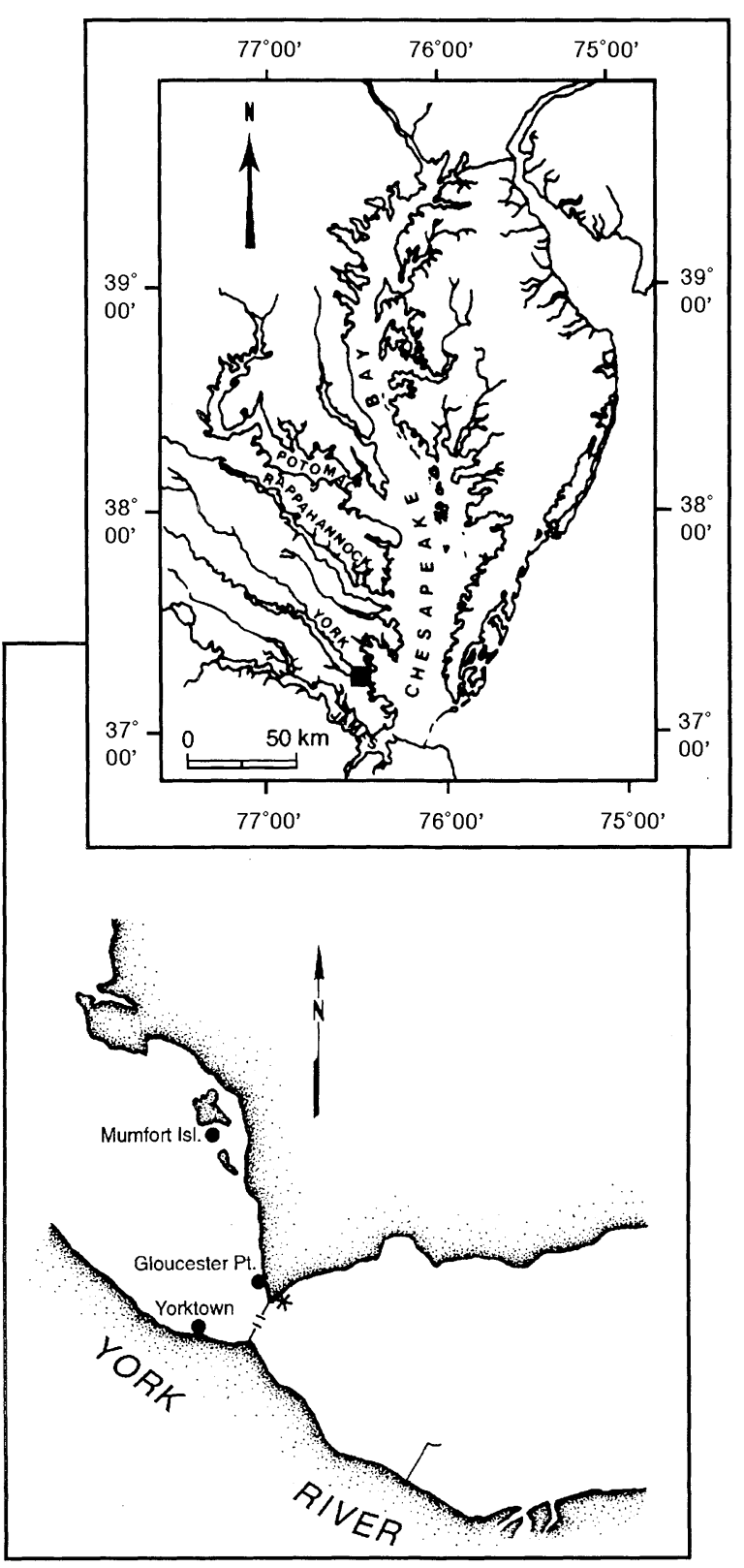

FIG. 1. Section of the York River, Virginia, in the lower Chesapeake Bay where this study was conducted. * indicates location of the wind gauge.

\section{Wind data}

Wind speed and direction data for September and October of 1989, 1990, and 1991 were obtained from a wind gauge (Vaisala Model WAA-15 anemometer fitted on a Vaisala Model WAD-14 analog indicator; Vaisala, Woburn, Massachusetts, USA) located less than a kilometre from the Gloucester Point site, $2 \mathrm{~km}$ from the Yorktown site and $5 \mathrm{~km}$ from the Mumfort Island (Fig. 1). Data were directly transmitted to the mainframe computer at the Virginia Institute of Marine 
Science and 6-min, time-averaged velocity vectors computed.

\section{Current simulations}

A three-dimensional computer model of circulation and transport is available for the York River estuary (Hamrick 1991, 1992a, b). The model partitions the water column into eight vertical segments, which vary in thickness with water depth and have a horizontal resolution of $500 \mathrm{~m}$ in the region of estuary where our study was conducted. The algorithm partitions the York River estuary into $>12000$ three-dimensional cells and predicts current speed and direction in each cell. Forcing functions in the model are freshwater inflow and tidal currents. The model has been well calibrated with field data (Hamrick 1991) and has proven to be an effective tool for predicting observed complex threedimensional flow patterns (Hamrick 1992a, $b$ ).

A model simulation was run with inputs typical of September during the low rainfall years of 1989,1990 , and 1991 (harmonic mean for freshwater inflow $=18.3$ $\mathrm{m}^{3} / \mathrm{s}$ ). With a time step equal to $1.03 \mathrm{~h}$, instantaneous horizontal velocity vectors were predicted for each cell throughout one tidal cycle. In the region of the seed broadcast experiments the near-bottom cell represented a region from the bottom to $9.4-18.75 \mathrm{~cm}$ above the bottom depending upon tidal stage. Near-bottom flows coupled with an approximation of bottom roughness $\left(z_{0}=10^{-2} \mathrm{~cm}\right)$ were used to provide first-order estimates of shear velocities $\left(u_{*}\right)$ using the relationship

$$
u_{*}=k \frac{d\left(U_{z}\right)}{d\left(\ln z / z_{0}\right)},
$$

where $k=$ von Karman's constant $=0.4$ and $U_{z}=$ velocity at height $z$ above the bed; the relationship holds in a restricted region above the bed.

This value is related to the shear stress imposed on the bottom by the currents and is the relevant parameter for addressing current-mediated transport of seeds.

\section{Seed transport characteristics}

Still water settling velocity. - Fifty seeds were randomly selected from field-collected lots as described above and lengths and widths measured to the nearest $0.1 \mathrm{~mm}$ using calipers. Masses to the nearest $0.1 \mathrm{mg}$ were determined for each seed. Seeds were retained in individually numbered vials so that subsequent transport characteristics could be related to individual size and mass measures.

Still water fall velocities were determined in a 4-m long, 8.9-cm diameter, Plexiglas settling tube. The tube was filled with $1 \mu \mathrm{m}$-mesh filtered seawater and salinity adjusted to $20 \mathrm{~g} / \mathrm{kg}$ using freshwater. Intervals of 10 $\mathrm{cm}$ were marked along the length of the wall; two of these intervals, beginning $90 \mathrm{~cm}$ down the tube, were used for determination of fall velocities. (Preliminary measurements determined the distance required to reach free fall velocity.) A video camera was focused at this section of the settling tube and the individually numbered seeds were introduced one at a time. Seeds were released individually in the center of the tube and passage of seeds through each of these $10-\mathrm{cm}$ intervals was timed from the video recording using a stopwatch; each seed was timed 3 times to provide variance estimates associated with the measurement procedure. Each seed was collected after use via a funnel and drain port at the bottom of the settling tube and returned to numbered vials for use in flume transport studies described below.

\section{Flume experiments}

Transport characteristics in moving water were determined in a seawater flume at the Virginia Institute of Marine Science Eastern Shore Laboratory in Wachapreague, Virginia. The flume is a $5-\mathrm{m}$ long, $0.5-\mathrm{m}$ wide, Plexiglas channel designed to model nonoscillatory, turbulent flows in the benthic boundary layer. Pressure is maintained at a constant level in a $2.08 \mathrm{~m}^{3}$ head tank, from which outflow is controlled by a $8-\mathrm{cm}$ gate valve. A honeycombed collimator reduces the scale of turbulent eddies as the water enters the channel and a vaned exit weir allows for control of water depth. Water is returned from the tail tank to the head tank with two swimming pool pumps controlled by float switches in the tail tank. Dye flow studies have indicated steady, two-dimensional flow throughout the working section of the flume. Bed roughness in the flume may be manipulated by adding sediment or by inserting a false bottom with sandpaper attached; both approaches were used in the experiments described below. Shear velocity $\left(u_{*}\right)$ was calculated from velocity profiles above the flume bed obtained with a TSI hot film probe and anemometry system according to Eq. 1 .

We investigated the downstream transport of seeds suspended in a turbulent boundary layer under the following conditions. A false bottom in the flume with 120 grit sandpaper was inserted into approximately the first $4 \mathrm{~m}$ of the flume and clean, well-sorted foundry sand $(400 \mu \mathrm{m}<$ grain size $<425 \mu \mathrm{m})$ was added to the downstream region of the flume $(\approx 1 \mathrm{~m})$ to create a smooth bed. The flume was filled with $1 \mu \mathrm{m}$-mesh filtered seawater diluted with freshwater to yield 20 $\mathrm{g} / \mathrm{kg}$. Water depth $(D)$ in the flume was $10 \mathrm{~cm}$; freestream velocity $\left(U_{\infty}\right)$ was $8 \mathrm{~cm} / \mathrm{s} ; u_{*}=0.7 \mathrm{~cm} / \mathrm{s}$. These conditons provided for reasonable dynamic similarity (boundary Reynolds number, $\mathrm{Re}_{*}=u_{*} d / v=6$ and Froude number, $\mathrm{Fr}=U /[g D]^{1 / 2}=0.07$ ) with typical field conditions. Seeds were released at the water surface in the centerline and the distance transported downstream recorded. Fig. 2 provides a schematic of the set-up and vertical velocity distribution. Still water fall velocities were used together with mean flow velocity in the flume to calculate a predicted travel distance downstream for each seed as: 


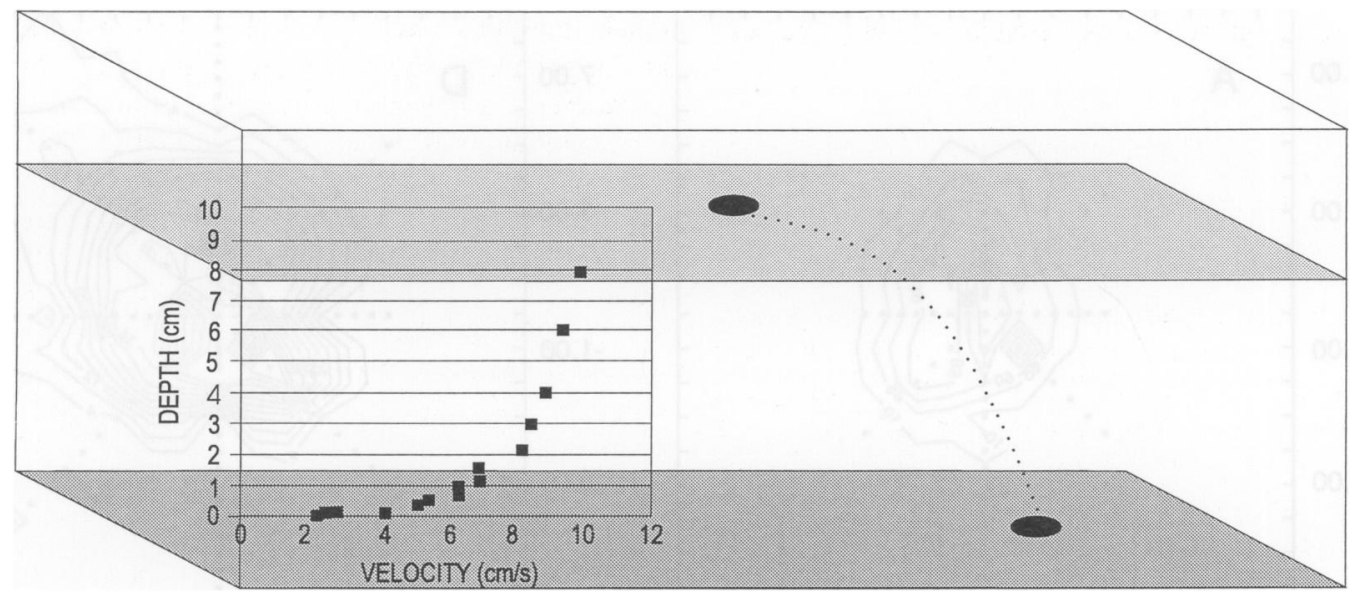

FIG. 2. Schematic representation of seed transport in the boundary-layer flume. Time-averaged vertical velocity profile is shown in insert.

Predicted horizontal transport distance

$$
\begin{gathered}
=\frac{\text { height above the bed }(\mathrm{cm})}{\text { still water fall velocity }(\mathrm{cm} / \mathrm{s})} \\
\times \text { freestream velocity }(\mathrm{cm} / \mathrm{s})
\end{gathered}
$$

These predicted distances were then compared with actual distances to evaluate seed fall characteristics in shear flows.

Transport characteristics of seeds resting on the bottom were investigated using the same individually numbered seeds and similar conditions in the flume. Ten seeds were placed on the sand portion of the bed $\approx 25 \mathrm{~mm}$ apart in a cross-channel direction; thus the working section of the flume spanned less than onehalf of the flume and side wall effects were minimal. Orientation of the long axis of the seeds was haphazard. Flow velocity was gradually increased until seeds were observed to move. We noted the manner of transport of seeds (e.g., bedload, saltation, suspension), whether or not sediment was being transported, and obtained velocity profiles to determine the critical erosion shear velocity $\left(u_{\text {crit }}\right)$. The procedure was repeated 4 times with new batches of seeds to obtain estimates for all 50 seeds.

\section{RESULTS}

\section{Seed dispersal experiments}

In each of $3 \mathrm{yr}$ and at the different sites, $80 \%$ or greater of the seeds that germinated remained within the $5 \mathrm{~m}$ diameter plots (Table 1). In the 1989 experiments, the maximum distance a seedling was observed from the center of the circle was $4.5 \mathrm{~m}$. In the 1990 and 1991 experiments, the maximum distance a seedling was observed from the center of the circle was 10 and $14 \mathrm{~m}$, respectively. The number of seedlings per plot based on the number of viable seeds broadcast onto the plots ranged from $3.8 \%$ at the 1990 Mumfort Island plot to $39.8 \%$ at the 1990 Gloucester Point site.
Averaged contour plots indicate that seedling abundance generally was greatest closest to the center of the plot and decreased with increasing distance from the center (Fig. 3A-F). Seedling abundance in both the 1990 and 1991 Gloucester Point plots exhibited a skewed distribution in different quadrats in the different years: southeast in 1990 and northeast in 1991, reflecting the direction of tidal currents at the time of broadcasting.

\section{Wind}

Wind velocity data illustrate several windy periods during September and October of each year (Fig. 4). In 1989 and 1990, 6-min time-averaged wind speeds in excess of $40 \mathrm{~km} / \mathrm{h}$ were observed on $\geq 12 \mathrm{~d}$ between seed broadcasts and the end of October; speeds as high as $72 \mathrm{~km} / \mathrm{h}$ (gale force) were recorded at least once during these periods. Calmer conditions prevailed in

TABle 1. Seed broadcasts, germination, and dispersal estimates from each of $3 \mathrm{yr}$. Year represents the year of the broadcasts; seedlings were censused in the following year. See Fig. 1 for site locations. $N$ represents the number of 5 $\mathrm{m}$ diameter plots per site. Mean number is given for numbers of seedlings per plot while standard deviations are given in parentheses for those data from locations with

\begin{tabular}{|c|c|c|c|c|c|c|}
\hline Year & Site* & $N \dagger$ & $\begin{array}{l}\text { Approxi- } \\
\text { mate no. } \\
\text { broad- } \\
\text { cast/plot }\end{array}$ & $\begin{array}{c}\text { Esti- } \\
\text { mate } \\
\text { no. } \\
\text { seed- } \\
\text { lings/ } \\
\text { plot }\end{array}$ & $\begin{array}{c}\% \text { of } \\
\text { seedlings } \\
\text { w/i } 5 \mathrm{~m} \\
\text { diam }\end{array}$ & $\begin{array}{c}\text { Max. } \\
\text { dis- } \\
\text { tance } \\
\text { (m from } \\
\text { center) }\end{array}$ \\
\hline 1989 & GP & 1 & 30000 & 9007 & 93 & 4.5 \\
\hline 1989 & YK & 1 & 30000 & 5701 & 92 & 4.5 \\
\hline 1989 & MI & 1 & 30000 & 5243 & 90 & 4.5 \\
\hline 1990 & GP & 3 & 20000 & 7975 & $80(7.1)$ & 10.0 \\
\hline 1990 & MI & 3 & 20000 & 751 & $88(5.7)$ & 4.0 \\
\hline 1991 & GP & 6 & 40000 & 3818 & $86(3.3)$ & 14.0 \\
\hline
\end{tabular}
multiple plots $(\mathrm{w} / \mathrm{i}=$ within $5 \mathrm{~m}$ diameter circle).

* GP = Gloucester Point, Virginia; YK = Yorktown, Virginia; MI = Mumfort Island, Virginia. 

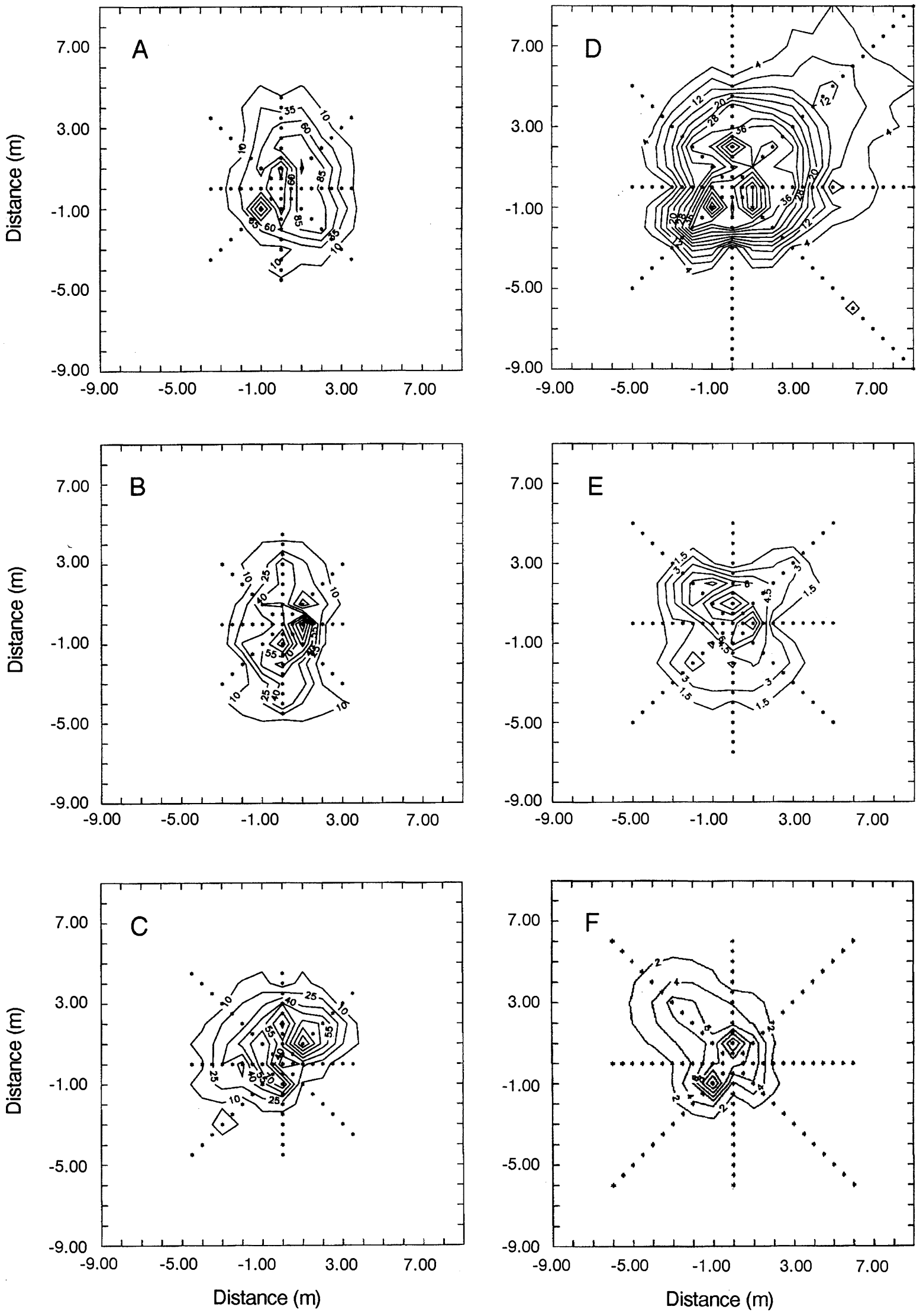
1991 , but wind speeds $>32 \mathrm{~km} / \mathrm{h}$ were common and $64 \mathrm{~km} / \mathrm{h}$ winds were recorded on 18 October.

\section{Model simulations}

The hydrographic model simulation of current velocities in the York River provided instantaneous estimates of velocity vectors for $>12000$ cells $\times 12$ time intervals over a tidal cycle. We inspected the output for near-bottom current velocities in the vicinity of our field sites and report the results for maximum flood and ebb tide values only. Maximum near-bottom currents at the Gloucester Point site were predicted to be $20 \mathrm{~cm} / \mathrm{s}$ and $19.5 \mathrm{~cm} / \mathrm{s}$ for flood and ebb tides, respectively (Fig. 5A, B). Estimates of maximum shear velocities derived from these values were $1.26 \mathrm{~cm} / \mathrm{s}$ for flood tide and $1.20 \mathrm{~cm} / \mathrm{s}$ for ebb tide (see Appendix for computations). Current velocities and boundary shears at the Yorktown and Mumfort Island sites were similar to those reported here for Gloucester Point.

\section{Seed transport characteristics}

Values for seed size, mass, and still water settling velocity are shown in Table 2 . In still water seeds settled quickly with their long axis normal to the direction of fall; end-over-end tumbling was not observed. In a turbulent boundary-layer flow, where tumbling might be expected seeds fell similarly to the still water condition and the distances traveled downstream before striking the bed were similar to those predicted from still water settling velocities and mean flow (Fig. 6). Slightly higher predicted horizontal transport distances resulted from our simplified approach, which ignored the velocity gradient and calculated predicted distances as a function of freestream velocity (Eq. 2).

The erosion threshold $\left(u_{*_{\text {crit }}}\right)$ for $Z$. marina seeds in these experimental conditions was $0.7 \mathrm{~cm} / \mathrm{s}, \approx 60 \%$ of predicted maximum $u_{*}$ from field sites. Ten percent of the seeds began to move at this flow and very slight increases in the flow resulted in the movement of most seeds. Seeds were always observed to move as bedload, sometimes with intermittent periods of rolling and stopping. The erosion threshold for seeds was well below that of the noncohesive sand bed and no sediment transport was observed at the flow that initiated seed movement. Resuspension of seeds from the bed was not observed, even under the maximum flows, which caused general bed erosion ( $u_{*}$ not determined).

\section{Discussion}

Seedling distribution patterns in all $3 \mathrm{yr}$ reflected conditions at the time of broadcasting and indicate little subsequent dispersal. Howe and Smallwood (1982: 204) noted that "the ultimate null hypothesis [for the
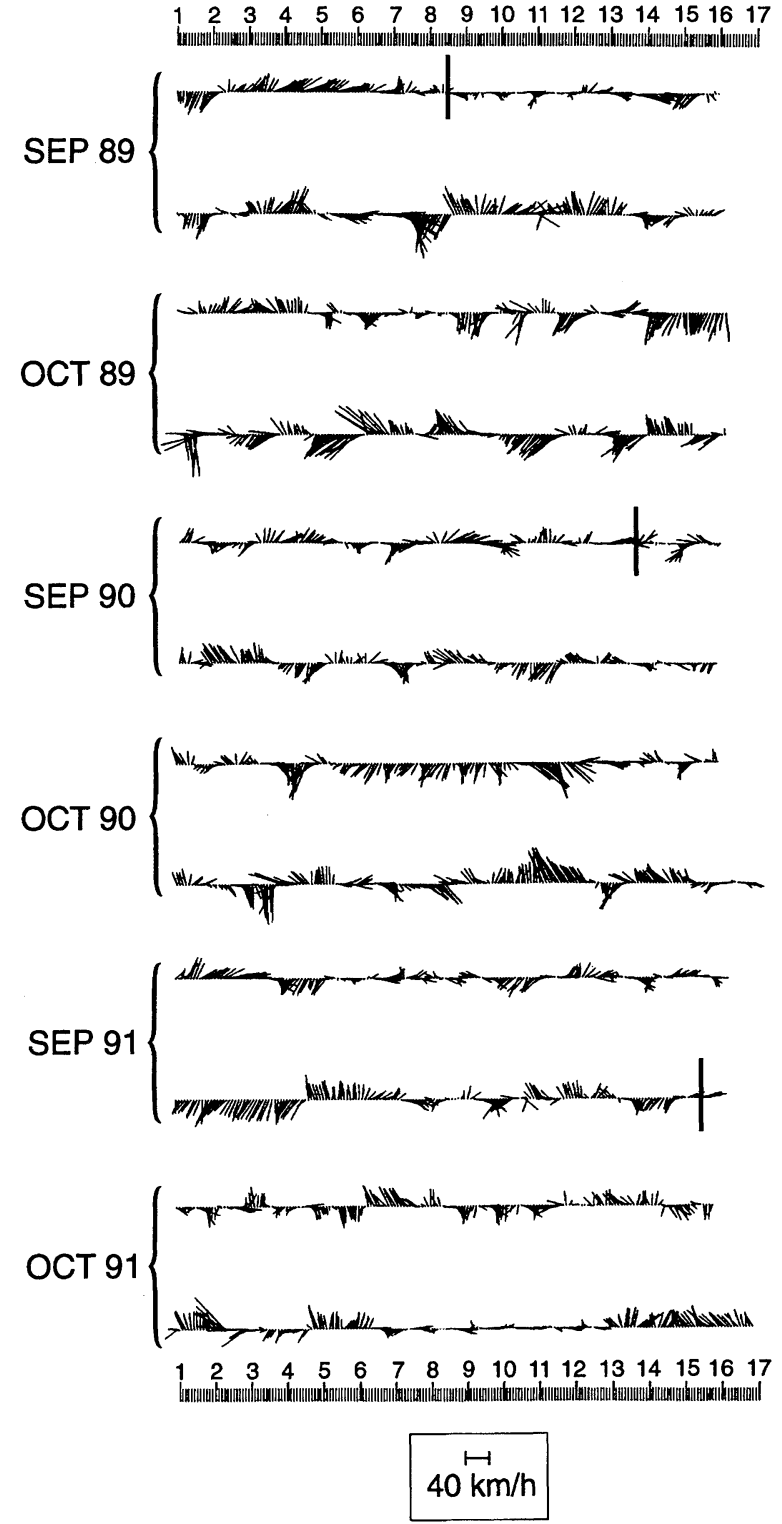

FIG. 4. Wind velocity vectors for September and October in each year of seed broadcasts. Vectors are 6-min time averages throughout the entire 2 -mo period; north is towards the top of the page. The scales at top and bottom are days and each month is arranged in two lines with the first half in the upper line and the second in the lower. The vertical bar in September of each year indicates the date of seed broadcasts.

three selective hypotheses listed above] is that adult distributions closely reflect seed distributions." Rapid settling velocities for seeds, the lack of dispersal-enhancing mechanisms and the proximity of seedlings to

FIG. 3. Averaged contour plots of seedling abundance for the $3 \mathrm{yr}$ for the three different sites: (A) 1989, Gloucester Point; (B) 1989, Mumfort Island; (C) 1989, Yorktown; (D) 1990, Gloucester Point; (E) 1990, Mumfort Island; (F) 1991, Gloucester Point. 


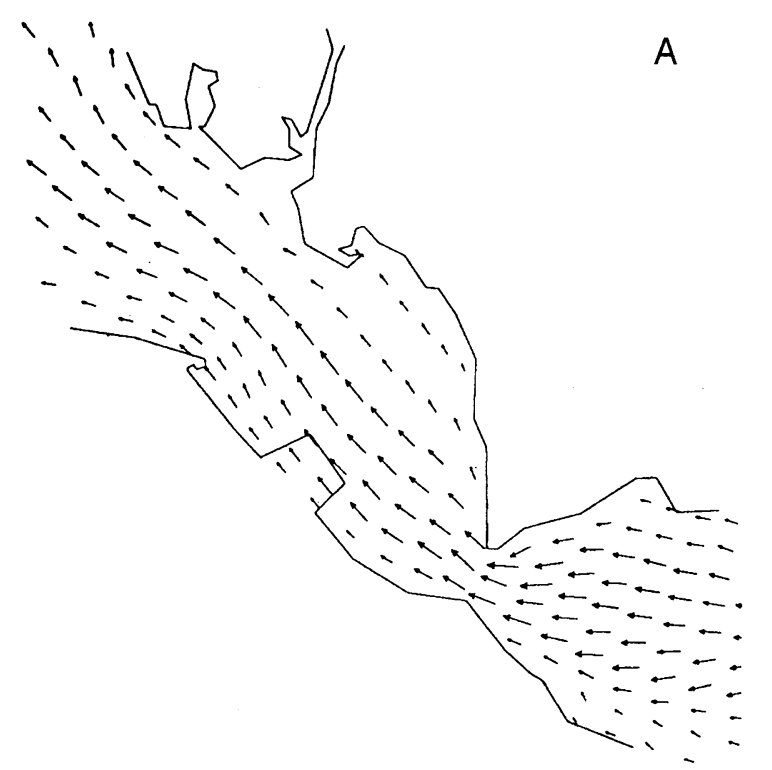

\begin{tabular}{l|l|l|l|l|llllllll|l|l|}
\hline 1 & 1 & 1 & 1 & & 1 & 1 & 1 & 1 & 1 & 1 \\
6 & 5 & 4 & 3 & 2 & 1 & 0 & 1 & 2 & 3
\end{tabular}
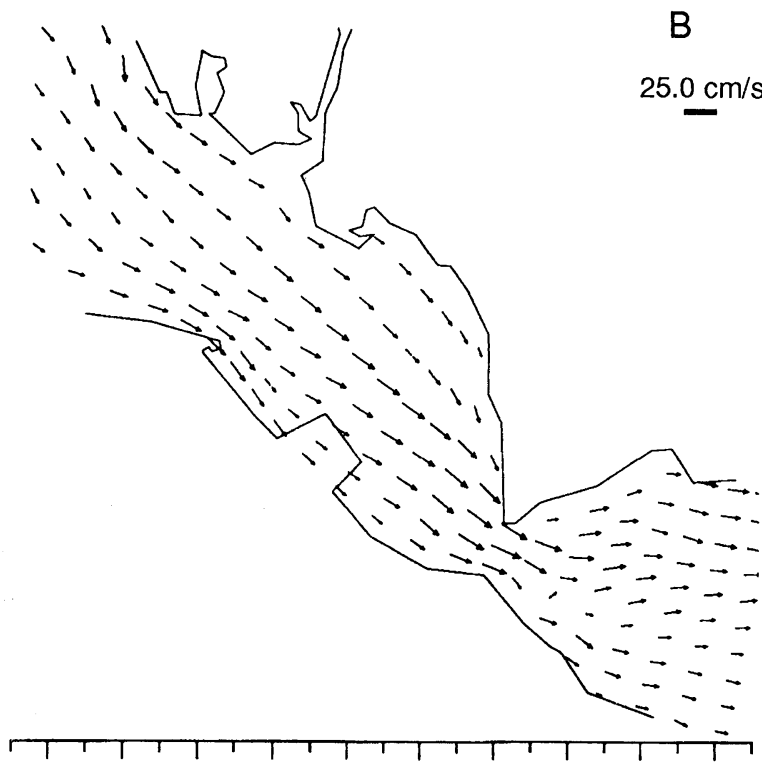

$\begin{array}{llllllllll}6 & 5 & 4 & 3 & 2 & 1 & 0 & 1 & 2 & 3\end{array}$

$\mathrm{km}$

FIG. 5. Maximum predicted near-bottom instantaneous velocities for September in the study area. (A) flood tide, (B) ebb tide. The scale at the bottom provides distance from an arbitrary origin at Gloucester Point, the small bar provides scaling for the magnitude of the velocities.

the seed release sites all suggest that seed dispersal distances are relatively short. Our results do not directly address the proportional mortalities of seeds and seedlings in the vicinity of adults (the escape hypothesis), since broadcasts were done in unvegetated areas but, as discussed below, dispersal potentials for seeds from established beds is expected to be lower than observed here. Certainly, these findings do not support
TABLE 2. Zostera marina seed size and still water fall velocity. Values are means and standard deviations for 50 seeds.

\begin{tabular}{cccc}
\hline \hline $\begin{array}{c}\text { Length } \\
(\mathrm{mm})\end{array}$ & $\begin{array}{c}\text { Width } \\
(\mathrm{mm})\end{array}$ & $\begin{array}{c}\text { Mass } \\
(\mathrm{mg})\end{array}$ & $\begin{array}{c}\text { Fall velocity } \\
(\mathrm{cm} / \mathrm{s})\end{array}$ \\
\hline $3.0 \pm 0.49$ & $1.3 \pm 0.23$ & $3.6 \pm 0.9$ & $5.96 \pm 1.14$ \\
\hline
\end{tabular}

a role for current-driven seed transport in the colonization of distant, disturbed habitats (the colonization hypothesis). Likewise the limited dispersal capabilities of $Z$. marina seeds does not support a selective advantage associated with dispersal to widely distributed, specialized microhabitats (the directed dispersal hypothesis).

The barrel-shaped seeds of $Z$. marina exhibit atelochory (a lack of dispersal enhancing characteristics, e.g., pappi or wings); in both still water and in a boundary-layer current seeds fall rapidly. Both the height above the bottom and current speed used in the flume experiments are likely to be lower than most values encountered in natural $Z$. marina beds, at least during some tidal stages. In shallow water areas $(<0.5 \mathrm{~m}$ at mean low water) of Chesapeake Bay, reproductive shoots are shorter than in slightly deeper waters and some seeds may be only $10 \mathrm{~cm}$ above the bottom. In addition, at low tide longer reproductive shoots may be lying on the surface with seeds much closer to the sediment surface than at high tide when reproductive shoots are more erect. Using our measured still water settling velocities and the justification of only slight over-estimation provided by Fig. 6, we provide some predicted distances for transport through the water column over a range of reproductive shoot height and free-stream velocity (Table 3 ). It is clear that even at the extremes of height above the bed and water velocity expected for $Z$. marina in natural habitats seed dispersal by this means is expected on spatial scales no greater than the extent of seagrass meadows themselves.

Seeds were, however, transported readily as bedload in the flume experiments. The critical erosion velocity

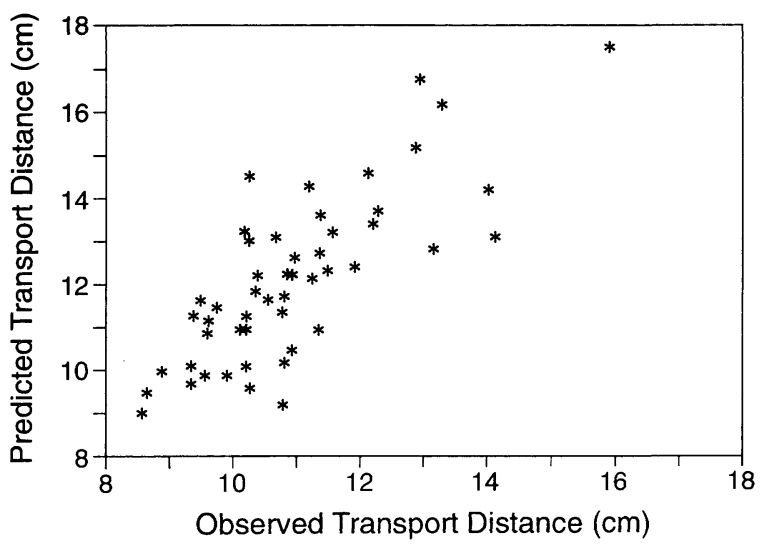

FIG. 6. Predicted vs. observed transport distances in the seawater flume. Predicted distances computed as in Eq. 2. 
required to initiate movement of seeds in the flume was well below that required to move the noncohesive sand on the flume bed. We observed that very small surface relief, on the order of one to a few millimetres, inadvertently created during the construction of the "smooth" sand bed, was sufficient to trap seeds. The lack of evidence for seed redistribution in the field after initially striking the bottom suggests that topographic armoring/shielding of seeds from the flow that was observed in the flume is likely acting in these field sites as well. Within natural grass beds current velocities are significantly dampened from drag exerted by the grass (Fonseca et al. 1982, Fonseca and Fisher 1986, Gambi et al. 1990) effectively armoring much of the bed. Thus transport of seeds from within grass beds is expected to be reduced beyond that observed here.

Wind records indicate several periods in all years with significant wind events, with gale-force winds occurring during 2 of the $3 \mathrm{yr}$. We lack data on sediment resuspension via wind-induced waves and currents at this site, but nevertheless find it is surprising that significant redistribution is not evident as a result of these events. The magnitude of maximum near-bottom currents predicted by the hydrographic model (which does not incorporate wind forcing) and our estimations of shear velocities provided further evidence that geophysical forces should be adequate to redistribute seeds. Estimates of maximum $u_{*}$ values from the field exceed $u_{*_{\text {crit }}}$ required to transport seeds as bedload. The observation that seedling distributions reflect current conditions at the time of broadcasting with no indicaton of redistribution suggests that seeds on the bottom are armored from the flow by topographic features of the sediments.

Our findings suggest the following scenario. Seeds fell rapidly to the bottom after broadcasting, dispersing only up to a few metres under the influence of currents. Microtopography relief on the seafloor armored seeds from flow such that subsequent tidal flows did not dramatically change distribution patterns. We presume rapid incorporation into the sediments followed since the seeds were apparently not further dispersed during significant wind events over subsequent weeks.

An alternative interpretation of our findings is suggested by the relatively low observations of seedlings relative to the numbers broadcast. Since seedling numbers generally fell between 10 and $40 \%$ (and in one case only $3.8 \%$ ) of seeds broadcast, we could postulate that the majority of seeds were transported and germinated far afield from the experimental plots and that the pattern we observed is neither reflective of the overall seed distribution nor indicative of the adaptive value of seed dispersal. We discount this for several reasons. First, the region of the York River chosen for these experiments is ideally suited for evaluating dispersal over larger scales than explicitly measured here. A long-term transplant effort in this area has established that $Z$. marina planted in the fall can survive through the winter and grow through most of the spring (Batiuk et al.
TABLE 3. Predicted horizontal dispersal distances for Zostera marina seeds at various release heights above the bottom over a range of current speeds.

\begin{tabular}{ccc}
\hline \hline $\begin{array}{c}\text { Release height } \\
(\mathrm{cm})\end{array}$ & $\begin{array}{c}\text { Current speed } \\
(\mathrm{cm} / \mathrm{s})\end{array}$ & $\begin{array}{c}\text { Horizontal } \\
\text { distance } \\
\text { traveled }(\mathrm{m})\end{array}$ \\
\hline 10 & 10 & 0.17 \\
10 & 30 & 0.50 \\
10 & 100 & 1.68 \\
30 & 10 & 0.50 \\
30 & 30 & 1.51 \\
30 & 100 & 5.03 \\
100 & 10 & 1.68 \\
100 & 30 & 5.03 \\
100 & 100 & 16.78 \\
\hline
\end{tabular}

1992). However, high turbidity during the late spring and early summer in some years decreases light penetration below the point required to sustain plants, resulting in complete mortalities during the summer. Regular surveys of our experimental area, both areal and from the water, of a 7.4 ha area adjacent to and upstream of Gloucester Point (see Fig. 1) have not recorded any $Z$. marina at this site other than those indicated in and near the experimental plots. Regular observations of the experimental plots by snorkeling showed no seedlings between replicates in the 1990 and 1991 experiments.

We further discount the interpretation that most seeds dispersed to and germinated outside of the experimental area by pointing out the effects of environmental factors on seed germination. Though some laboratory studies have achieved high germination rates at extremes of temperature and salinity (e.g., Phillips et al. 1983, Hootsmans et al. 1987), under more realistic conditions a negative relationship between oxygen concentration and germination rate has been observed (Churchill 1992, Moore et al. 1993). Results from the two aforementioned studies indicate that seeds buried in hypoxic and anoxic conditions in the vicinity of the redox-potential discontinuiity (RPD) germinate more rapidly than those in oxygenated conditions. Likewise, Bigley (1981) found highest germination rates for $Z$. marina in the field at the anaerobic-aerobic interface. In that same study, viable seeds found well below the RPD, up to $15 \mathrm{~cm}$ deep, had significantly reduced germination success, because hypocotyls fail to reach the sediment surface, suggesting that seeds buried too deep may be lost to the population (Bigley 1981). Thus, germination success would appear to depend upon the fortuitous burial of seeds to a narrow depth interval within the sediment by physical or biological processes.

Finally, we note that in better studied terrestrial systems "most seeds fail to become established as seedlings" (Harper 1977, Cook 1979, Zammit and Westoby 1987). Though viability of seeds in the laboratory is generally high, the variety of potential fates awaiting seeds and seedlings in natural environments assures a lower recruitment success rate. Z. marina seeds in this habitat are apt to be subject to predation and damage 
by infauna, mobile epifauna, and demersal fishes. Wigand and Churchill (1988) found that 5 of 10 species of crustaceans, molluscs, and fish from Great South Bay, New York, consumed seeds. Several additional species in Virginia, most notably the blue crab, Callinectes sapidus, are potential predators on $Z$. marina seeds.

Faced with predation losses and restrictive burial constraints the seedling recruitment percentages we observed in the spring survey seem high rather than low. Though we cannot reject the thesis that some seeds were transported very far from the experimental plots and successfully germinated, the evidence clearly supports the scenario of limited dispersal and recruitment in the immediate vicinity of seed release.

Our interpretation of limited dispersal for $Z$. marina is consistent with observations for many wind-dispersed seeds in terrestrial systems. Harper (1977) reviewed data on distributions in relation to distance from their source for nonwinged, wind-dispersed seeds; modal distances were generally observed to fall within a radius equal to $1-2$ times the plant height. For aquatic (as for terrestrial) vegetation geophysical dispersal will be a function of seed fall velocity, height above the bottom (ground), and the velocity and turbulence regimes of the water (wind). In the shallow-water estuarine system in this study wind- and tidal-forced water movements exert greater drag at the fluid-substrate interface than generally occurs at wind-ground interfaces, thus providing the potential for and expectation of redistribution after settlement. Observed seedling distributions for $Z$. marina, nevertheless, revealed limited dispersal and reflected current conditions at the time of release despite the occurrence of strong semidiurnal tidal currents and numerous significant wind events. In one of the earlier studies on $Z$. marina Tutin (1938) reported limited seed dispersal, with the greatest distance observed for a seedling from a mature plant being $1.32 \mathrm{~m}$.

Though seed dispersal capabilities are clearly limited for $Z$. marina, its cosmopolitan distribution and occasional reestablishment in isolated habitats (e.g., Chincoteague Bay, Virginia, Orth et al. 1992) is indicative of some dispersal potential. Evidence from seagrass distributional surveys in Chesapeake Bay suggest that new seagrass beds occasionally become established up to $7.3 \mathrm{~km}$ from existing populations (Orth et al. 1992). Seed dispersal may be enhanced by transport at the air-water interface via gas bubbles produced by the plant, which attach to the seed at the time of release, though this phenomenon has not been widely reported. Churchill et al. (1985) found seeds transported by this means for up to $200 \mathrm{~m}$, floating for $>40 \mathrm{~min}$ under relatively calm conditions. We cannot evaluate the importance of this means of seed dispersal in $Z$. marina.

Additionally, in Chesapeake Bay the potential for reproductive shoots to become dislodged and raft greater distances with seeds may be enhanced by dis- turbances, such as those associated with the feeding of schools of cownose rays (Orth 1975), which are abundant in Chesapeake Bay in late spring and summer, or storms. During our collection of reproductive shoots for seeds for these experiments we often observed individual reproductive shoots with seeds floating on the surface over the seagrass bed. Presumably, these shoots can be exported from the bed releasing seeds during transport. Similar observations have been made of rafting reproductive shoots along both the Pacific (McRoy 1968, Phillips and Backman 1983) and Atlantic coasts of North America (Gates 1984). Spread of Z. marina to areas distant from source populations may be a function of unpredictable, episodic storm or biological events that result in detached reproductive shoots with viable seeds being transported long distances via surface currents, but these remain to be quantified.

Although fish and waterfowl can serve as vehicles for seed dispersal through ingestion and elimination of seeds (Martin et al. 1951, Agami and Waisal 1986, 1988) we suggest these mechanisms are not operable in Chesapeake Bay $Z$. marina communities. $Z$. marina seeds have been found in stomachs of several fish species collected from seagrass beds in Chesapeake Bay (R. J. Orth, unpublished data) and North Carolina (Adams 1976) but the viability of seeds ingested and eliminated by these species is unknown. Z. marina seeds do not have a thick-walled seed coat (Taylor 1957a) (compared to $R$. maritima, a co-occurring species in our area: Orth and Moore 1988) and can potentially be easily damaged by fish and waterfowl ingestion. $Z$. marina seed germination occurs in late October to early November (Moore et al. 1993), normally before the arrival of many wintering waterfowl species that could potentially consume these seeds (Wilkins 1982). We discount the possibility of germinated seeds as dispersal agents because the delicate nature of the seedling (Taylor 1957b) makes it easily susceptible to crushing during the ingestion process. Nevertheless, migrating waterfowl may be relatively more important in $Z$. $m a-$ rina populations at more northern latitudes where seed germination occurs later than Chesapeake Bay (Churchill 1983; F. T. Short, personal communication) and where seeds would be consumed and eliminated before they germinated.

These findings have implications for environmental management and restoration goals in shallow-water temperate estuaries. $Z$. marina distributions are not expected to be "linked solely to environmental quality" (Dennison et al. 1993:87), but rather to reflect a strong historical component resulting from limited dispersal capabilities. A particularly important historical event affecting $Z$. marina distribution was the occurrence during the 1930s of the "wasting disease," which caused dramatic declines in abundance throughout the species range (Rasmussen 1973). After several decades of recovery further declines associated with reduced water quality were observed in the late 1960s and early 1970 s 
(Orth and Moore 1983a, 1984). With improving water quality resulting from regional environmental management (e.g., in Chesapeake Bay: Batiuk et al. 1992) reestablishment of $Z$. marina will reflect not only local conditions but regional biogeographical distributions, which still bear the mark of the changes over the six previous decades. Our data suggest that recovery of $Z$. marina beds following local extinction will proceed slowly and that a negative correlation may exist between reestablishment and distance to source populations over scales as small as metres to kilometres to tens of kilometres. If local environmental conditions change subsequent to a die-off, seagrass beds may never recover even if seeds eventually are transported to the area (e.g., increased water column turbidity and nutrients as a possible result from changes in run-off patterns from surrounding watersheds could result in inadequate light to support growth of seagrass: Duarte 1991, Dennison et al. 1993). This may explain, in part, the lack of recovery of many $Z$. marina beds along sections of the mid-Atlantic coast (Orth 1978) following the 1930s wasting disease.

The limited dispersal capabilities of seeds underscore the need to address questions of seagrass ecology in the context of landscape-scale distributional patterns and metapopulation analyses. The influence of immigration on local population (patch) dynamics and colonization of new patches will be a function of regional distribution patterns. Gotelli (1991) categorized metapopulation models according to the dependence (or independence) of immigration and extinction rates on regional occurrence patterns. Independence of immigration implies a "propagule rain" (sensu Harper 1977), while dependence of extinction rate on regional occurrence affords a "rescue effect" (e.g., Brown and Kodric-Brown 1977, Hanski 1982). Our results clearly indicate that a propagule rain is not to be expected far from source populations; effects of regional abundance on local extinction have yet to be examined. For $Z$. marina local conditions (e.g., light attenuation and substrate type) will play a role in the establishment and maintenance of meadows, and patch size will influence seed production (e.g., through pollination success), but on a bay-wide scale the distribution of patches may control colonization rates and the spread of $Z$. marina. Active restoration efforts must therefore consider not only local habitat suitability, but also patch size and patch spacing in relation to regional hydrographic patterns.

\section{ACKNOWLEDGMENTS}

We gratefully acknowledge the following people for their participation in the different aspects of this study: seed collection-Jill Goodman, Curtis Harper, Lori Morris, Sheryl Robertson Willes, and the many volunteers and students who assisted over the three years; assistance in the flume experiments-Terry Tompson, Rudy Cashwell, and Jake Taylor; data analysis-Jamie Fishman; wind data analysis-Gary Anderson; model simulation of current velocity - Dr. John Ham- rick; helpful comments on earlier versions of the manuscript-Rom Lipcius, Mark Patterson, Linda Schaffner, and two anonymous reviewers. This project was funded by Virginia's Chesapeake Bay Initiatives and a grant from Allied Signal Foundation.

Contribution Number 1841 from the Virginia Institute of Marine Science, College of William and Mary.

\section{LITERATURE CITED}

Adams, S. M. 1976. Feeding ecology of eelgrass fish communities. Transactions of the American Fisheries Society 105:514-519.

Agami, M., and Y. Waisal. 1986. The role of mallard ducks (Anas platyrhynchos) in distribution and germination of the submerged hydrophyte Najas marina L. Oecologia 68:473475.

Agami, M., and Y. Waisal. 1988. The role of fish in distribution and germination of the submerged macrophytes $\mathrm{Na}$ jas marina L. and Ruppia maritima L. Oecologia 76:8388.

Arasaki, M. 1950. Studies on the ecology of Zostera marina and Zostera nana. Bulletin of the Japanese Society of Scientific Fisheries 16:70-76.

Batiuk, R. A., R. J. Orth, K. A. Moore, W. C. Dennison, J. C. Stevenson, L. Staver, V. Carter, N. Rybicki, R. E. Hickman, S. Kollar, S. Bieber, and P. Heasly. 1992. Chesapeake Bay submerged aquatic vegetation habitat requirements and restoration targets: a technical synthesis. U.S. Environmental Protection Agency, Chesapeake Bay Program CBP/TRS 83/92.

Bigley, R. E. 1981. The population biology of two intertidal seagrasses, Zostera marina and Ruppia maritima, at Roberts Bank, British Columbia. Thesis. University of British Columbia, Vancouver, British Columbia, Canada.

Brown, J. H., and A. Kodric-Brown. 1977. Turnover rates in insular biogeography: effects of immigration on extinction. Ecology 58:445-449.

Brown, J. S., and D. L. Venable. 1986. Evolutionary ecology of seed-bank annuals in temporarily varying environments. American Naturalist 127:31-47.

Cambridge, M. L., and A. J. McComb. 1984. The loss of seagrasses in Cockburn Sound, Western Australia. I. The time course and magnitude of seagrass decline in relation to industrial development. Aquatic Botany 20:229-243.

Churchill, A. C. 1983. Field studies on seed germination and seedling development in Zostera marina L. Aquatic Botany 16:21-29.

- 1992. Growth characteristics of Zostera marina L. seedlings under anaerobic conditions. Aquatic Botany 43: 379-392.

Churchill, A. C., G. Nieves, and A. H. Brenowitz. 1985. Flotation and dispersal of eelgrass seeds by gas bubbles. Estuaries 8:352-354.

Cook, R. E. 1979. Patterns of juvenile mortality and recruitment in plants. Pages 207-231 in O. T. Solibrig, S. Jain, G. B. Johnson, and P. H. Raven, editors. Topics in plant population biology. Columbia University Press, New York, New York, USA.

den Hartog, C. 1970. The seagrasses of the world. NorthHolland, Amsterdam, The Netherlands.

Dennison, W. C., R. J. Orth, K. A. Moore, J. C. Stevenson, V. Carter, S. Kollar, P. W. Bergstrom, and R. A. Batiuk. 1993. Assessing water quality with submersed aquatic vegetation. BioScience 43:86-94.

Duarte, C. M. 1991. Seagrass depth limits. Aquatic Botany 40:363-377.

Fonseca, M. S., and J. S. Fisher. 1986. A comparison of canopy friction and sediment movement between four species of seagrass with reference to their ecology and restoration. Marine Ecology Progress Series 29:15-22. 
Fonseca, M. S., J. S. Fisher, J. C. Zieman, and G. W. Thayer. 1982. Influence of the seagrass Zostera marina L. on current flow. Estuarine, Coastal and Shelf Science 15:351-364.

Gambi, M. C., A. R. Nowell, and P. A. Jumars. 1990. Flume observations on flow dynamics in Zostera marina (eelgrass) beds. Marine Ecology Progress Series 61:159-169.

Gates, K. L. 1984. A comparison of two Zostera marina L. seed banks in Great South Bay, New York. Thesis. Adelphi University, Garden City, New York, USA.

Giesen, W. B. J. T., M. M. van Katwijk, and C. den Hartog. 1990. Eelgrass condition and turbidity in the Dutch Wadden Sea. Aquatic Botany 37:71-85.

Gotelli, N. J. 1991. Metapopulation models: the rescue effect, the propagule rain, and the core-satellite hypothesis. American Naturalist 138:768-776.

Hanski, I. 1982. Dynamics of regional distribution: the core and satellite species hypothesis. Oikos 38:210-221.

Harper, J. L. 1977. Population biology of plants. Academic Press, New York, New York, USA.

Hamrick, J. M. 1991. Analysis of mixing and dilution of process water discharge into the Pamunkey River. Report to Chesapeake Corportion, Virginia Institute of Marine Science, Gloucester Point, Virginia, USA.

—. 1992a. A three-dimensional environmental fluid dynamics computer code: theoretical and computational aspects. Special Report Number 317 in Applied Marine Science and Ocean Engineering, Virginia Institute of Marine Science, Gloucester Point, Virginia, USA.

. 1992b. Estuarine environmental impact assessment using a three-dimensional circulation and transport model. Pages 292-303 in M. L. Spaulding et al., editors. Estuarine and coastal modeling. Proceedings of the Second International Conference, American Society of Civil Engineers, New York, New York, USA.

Hootsmans, M. J. M., J. E. Vermaat, and W. Van Vierssen. 1987. Seed-bank development, germination and early seedling survival of two seagrass species from the Netherlands: Zostera marina L. and Zostera noltii Hornem. Aquatic Botany 28:275-285.

Howe, H. F., and J. Smallwood. 1982. Ecology of seed dispersal. Annual Review of Ecology and Systematics 13:201228.

Martin, A. C., H. S. Zim, and A. L. Nelson. 1951. American wildlife and plants: a guide to wildlife food habits, the use of trees, shrubs, weeds, and herbs by birds and mammals of the United States. Dover, New York, New York, USA.

McRoy, C. P. 1968. The distribution and biogeography of Zostera marina (eelgrass) in Alaska. Pacific Science 22:507513.

Moore, K. A., R. J. Orth, and J. F. Nowak. 1993. Environmental regulation of seed germination in Zostera marina L. (eelgrass) in Chesapeake Bay: effects of light, oxygen and sediment burial. Aquatic Botany 45:79-91.

Orth, R. J. 1975. Destruction of eelgrass, Zostera marina, by the cownose ray, Rhinoptera bonasus, in the Chesapeake Bay. Chesapeake Science 16:205-208.

. 1978. Zostera marina. Pages $31-57$ in J. C. Stevenson and N. M. Confer, editors. Summary of available information on Chesapeake Bay submerged vegetation. United States Fish and Wildlife Service Biological Services Program FWS/OBS-78/66.

Orth, R. J., and K. A. Moore. 1983a. Chesapeake Bay: an unprecedented decline in submerged aquatic vegetation. Science 222:51-53

Orth, R. J., and K. A. Moore. 1983b. Seed germination and seedling growth of Zostera marina L. (eelgrass) in the Chesapeake Bay. Aquatic Botany 15:117-131.

Orth, R. J., and K. A. Moore. 1984. Distribution and abundance of submerged aquatic vegetation in Chesapeake Bay: an historical perspective. Estuaries 7:531-540.

Orth, R. J., and K. A. Moore. 1988. Distribution of Zostera marina L. and Ruppia maritima L. sensu lato along depth gradients in the lower Chesapeake Bay, U.S.A. Aquatic Botany 32:291-305.

Orth, R. J., J. F. Nowak, G. F. Anderson, K. P. Kiley, and J. R. Whiting. 1992. Distribution of submerged aquatic vegetation in the Chesapeake Bay and tributaries and Chincoteague Bay - 1991. U.S. Environmental Protection Agency, Chesapeake Bay Program, Annapolis, Maryland, USA.

Phillips, R. C., and T. W. Backman. 1983. Phenology and reproductive biology of eelgrass (Zostera marina $\mathrm{L}$.) at Bahia Kino, Sea of Cortez, Mexico. Aquatic Botany 17:8590.

Phillips, R. C., W. S. Grant, and C. P. McRoy. 1983. Reproductive strategies of eelgrass (Zostera marina L.). Aquatic Botany 16:1-20.

Rasmussen, E. 1973. Systematics and ecology of the Isefjord marine fauna. Ophelia 11:1-495.

Ridley, H. N. 1930. The dispersal of plants throughout the world. Reeve, Ashford, Kent, England.

Silberhorn, G. M., R. J. Orth, and K. A. Moore. 1983. Anthesis and seed production in Zostera marina L. (eelgrass) from the Chesapeake Bay. Aquatic Botany 15:133-144.

Taylor, A. R. A. 1957a. Studies of the development of Zostera marina L. I. The embyro and seed. Canadian Journal of Botany 35:477-499.

- 1957b. Studies of the development of Zostera marina L. II. Germination and seedling development. Canadian Journal of Botany 35:681-695.

Thayer, G. W., D. A. Wolfe, and R. B. Williams. 1975. The impact of man on seagrass systems. American Scientist 63: 288-296.

Tutin, T. G. 1938. The autecology of Zostera marina in relation to its wasting disease. New Phytologist 37:50-71.

van der Pijl, L. 1972. Principles of dispersal in higher plants. Second edition. Springer, Berlin, Germany.

Wigand, C., and A. C. Churchill. 1988. Laboratory studies on eelgrass seed and seedling predation. Estuaries 11:180183.

Wilkins, E. W. 1982. Waterfowl utilization of a submerged vegetation (Zostera marina and Ruppia maritima) bed in the lower Chesapeake Bay. Thesis. College of William and Mary, Gloucester Point, Virginia, USA.

Zammit, C., and M. Westoby. 1987. Seedling recruitment strategies in obligate-seeding and resprouting Banksia shrubs. Ecology 68:1984-1992. 


\section{APPENDIX}

Computation of shear velocity approximations for Gloucester Point field site.

\section{Assumptions}

1) The instantaneous horizontal velocity predicted by the model for the near bottom cell is characteristic of the velocity at the mid-point of the cell.

2) Total water depth $(D)$ at maximum flood tide is $0.75 \mathrm{~m}$ and at maximum ebb tide is $1.25 \mathrm{~m}$.

3) The bottom roughness height $\left(z_{0}\right)$ is $10^{-2} \mathrm{~cm}$.

4) A logarithmic velocity profile exists between the bottom $\left(z_{0}\right)$ and the middle of the bottom cell (Hamrick 1992a).

Flood

$U_{z}=$ velocity at mid-point of bottom cell $=19.5 \mathrm{~cm} / \mathrm{s}$. $U_{z 0}=$ velocity at the bottom $=0 \mathrm{~cm} / \mathrm{s}$.

$d=$ thickness of bottom cell $=D / 8=9.375 \mathrm{~cm}$. $d / 2=$ mid-point of bottom cell $=4.687 \mathrm{~cm}$. $\ln (d / 2)=1.545$.

$\ln \left(z_{0}\right)=-4.605$.

$k=$ von Karman's constant $=0.4$.

Substituting these values into Eq. 1:

$$
u_{*}=0.4 \frac{U_{z 0}-U_{z}}{\ln \left(z_{0}\right)-\ln (d / 2)}=1.26 \mathrm{~cm} / \mathrm{s} \text {. }
$$

$E b b$

$U_{z}=20 \mathrm{~cm} / \mathrm{s}$.

$d=125 / 8=15.625 \mathrm{~cm}$.

$d / 2=7.8125 \mathrm{~cm}$.

Substituting as above: $u_{*}=1.20 \mathrm{~cm} / \mathrm{s}$. 